\title{
Self-care practices regarding diabetes among diabetic patients in West Ethiopia
}

\author{
Mohammed Gebre Dedefo ${ }^{*}$, Balisa Mosisa Ejeta², Getu Bayisa Wakjira', Ginenus Fekadu Mekonen \\ and Busha Gamachu Labata'
}

\begin{abstract}
Objective: To assess the self-care practices and associated factors among diabetic patients in West Ethiopia.

Results: A total of 252 study participants were included in the study, of this $54.8 \%$ were male. Of the participants more than half 150 (59.5\%) had poor glycemic control and 153 (60.7\%) of the participants had good self-care. Majority of the study participants 209 (82.9\%) had adequate foot care and more than half 175 (69.4\%) and 160 (63.5\%) had adequate dietary plan and exercise management respectively. However of the total diabetic patients only 38 (15.1\%) had adequate blood glucose testing practices. On multivariable logistic analysis poor self-care practices were more likely to occur among male patients ( $A O R=5.551,95 \% \mathrm{Cl}=2.055-14.997, p=0.001$ ), patients living in rural area $(A O R=5.517,95 \% \mathrm{Cl}=2.184-13.938, \mathrm{p}<0.001)$, patients with duration of diabetes $<6$ years $(\mathrm{AOR}=41.023$, $95 \% \mathrm{Cl}=7.373-228.257, \mathrm{p}<0.001)$, patients with no access for self-monitoring blood glucose $(\mathrm{AOR}=9.448,95 \%$ $\mathrm{Cl}=2.198-40.617, \mathrm{P}=0.003)$, patients with poor knowledge about diabetes $(\mathrm{AOR}=67.917,95 \% \mathrm{Cl}=8.212-561.686$, $\mathrm{p}<0.001)$ and patients with comorbidities $(\mathrm{AOR}=18.621,95 \% \mathrm{Cl}=4.415-78.540, \mathrm{p}<0.001)$.
\end{abstract}

Keywords: Diabetes mellitus, Self-care practice, Diabetes knowledge, Glycemic control, Ethiopia

\section{Introduction}

Diabetes care is complex and requires that many issues, beyond glycemic control, be addressed [1]. The American Diabetes Association's (ADA's) Standards of Care are intended to provide clinicians, patients, researchers, payers, and other interested individuals with the components of diabetes care, general treatment goals, and tools to evaluate the quality of care. The management plan should recognize diabetes self-management education (DSME) and ongoing diabetes support as integral components of care [1-3].

According to the 2017 International Diabetes Federation (IDF) update, by the end of 2017, 4 million deaths will happen as a result of diabetes and its complications. Alongside other non-communicable diseases, diabetes is increasing most markedly in the cities of low and middle income countries. The IDF South-East Asia and Western

\footnotetext{
*Correspondence: mohamedg@wollegauniversity.edu.et

${ }^{1}$ Clinical Pharmacy Unit, Department of Pharmacy, College of Health Sciences, Wollega University, Nekemte, Oromia, Ethiopia

Full list of author information is available at the end of the article
}

Pacific regions are at the epicentre of the diabetes crisis: China alone has 121 million people with diabetes and India's diabetes population totals 74 million. African, Middle Eastern and Northern African and South-East Asian regions are expected to face the highest upsurge in the next 28 years. People from these regions develop disease earlier, get sicker and die sooner than their counterparts in wealthier nations $[4,5]$.

Previous studies had indicated that factors like older age, being male, lack of family/social support, lack of education, lack of knowledge about diabetes, presence of complications, being unemployed, poor adherence, lack of access for glucometer non-adherence to diet and exercise were significantly associated with poor self-care practices [6-17].

This study aimed at assessing the magnitude of selfcare practices and factors affecting self-care practices among diabetic patients; hence such types of data reveals the magnitude of the problem and are important for the care delivery services so as to fill the gaps to resolve the problem.

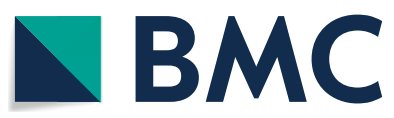

(c) The Author(s) 2019. This article is distributed under the terms of the Creative Commons Attribution 4.0 International License (http://creativecommons.org/licenses/by/4.0/), which permits unrestricted use, distribution, and reproduction in any medium, provided you give appropriate credit to the original author(s) and the source, provide a link to the Creative Commons license, and indicate if changes were made. The Creative Commons Public Domain Dedication waiver (http://creativecommons.org/ publicdomain/zero/1.0/) applies to the data made available in this article, unless otherwise stated. 


\section{Main text}

\section{Methods and materials}

Study design and period

A facility based cross-sectional study was conducted from February 20 to May 20, 2016.

\section{Study population}

Adult diabetic patients who were on active follow up in DM clinic during the study period, Nekemte Referral Hospital.

\section{Sample size determination and sampling technique}

The required sample size was determined by considering the following assumptions for interview questionnaires: Sample size is calculated by taking the proportion of poor glycemic control which is $73.1 \%$ on diabetes patients at Diabetes Clinic of Jimma University Specialized Hospital (JUSH) [11]. With 95\% confidence level and 5\% margin of error to get an optimum sample size.

$$
\mathrm{n}=\frac{(\mathrm{Z}-\alpha / 2)^{2} \mathrm{P}(1-\mathrm{P})}{\mathrm{d}^{2}}=\frac{(1.96)^{2} 0.731(1-0.731)}{(0.05)^{2}}=302
$$

Since the source population consisted of less than 10,000 respondents, the sample size was adjusted by using correction formula

$$
\mathrm{nf}=\mathrm{n} / 1+\mathrm{n} / \mathrm{N}
$$

where $\mathrm{nf}=$ the final sample size, $\mathrm{n}=$ desired sample size 302 and $\mathrm{N}=$ total diabetic patients (941). The calculated sample size was $\mathrm{nf}=229$. Considering a $10 \%$ nonresponse rate, 252 diabetic patients were included in the study.

\section{Inclusion and exclusion criteria}

All diabetic adult patients of age greater than or equal to 15 years who attended chronic care department for diabetic care at least for 1 year were included while diabetic patients who were critically ill, psychotic and/or unable to communicate with data collector due to other underlying medical disorder were excluded.

\section{Data collection tool}

To collect primary data, questionnaires and interview was used in the study. Data collection format was developed by the principal investigator to collect the blood glucose measurements and anti-diabetic medications used by respective study subjects. The questionnaire was developed after literatures were reviewed thoroughly [10-16].

\section{Definitions of terms}

Self-care practices Self-care practices refer to behaviors such as following a diet plan, increased exercise, self- blood glucose testing, and foot care [18]. Details about self-care activities were collected using the Summary Diabetes Self-Care Activities (SDSCA) [19] questionnaire after minor changes were made to it to suit the Ethiopian context. Four domains (diet, exercise, foot care and blood glucose testing) of self-care practices were used to assess the self-care practices of diabetic patients to diabetes. For all domains frequency of self-care activity in the last 7 days were measured. For each domain the mean was calculated and categorized as adequate for scores above mean value and unsatisfactory for scores less than mean value and presented as tables in result. Accordingly after calculating mean score, patients had adequate diet plan if scored $\geq 4$, patients had adequate foot care if scored $\geq 7$, patients had adequate exercise if scored $\geq 4$, patients had adequate self-blood glucose testing if scored $\geq 1$. The overall mean score was calculated by summation of the mean score for diet, exercise, foot care and blood glucose testing divided by the sum of number of questions under each scale. After calculating an overall mean score, it was classified as having good self-care practice if the patient scored $\geq 4$ or poor self-care practice if the patient scored $<4$.

Glycemic control Glycemic control was assessed by using Fasting Blood Glucose (FBG) level. The glycemic recommendation for non-pregnant adults is in between 70 and $130 \mathrm{mg} / \mathrm{dl}$, when the patients FBG was beyond this value we considered as poor glycemic control according to ADA [3].

Diabetes knowledge The Diabetes Knowledge Test (DKT) was utilized to assess diabetic patients' general understanding of their disease and treatment recommendations. The DKT was developed and tested for reliability and validity by the University of Michigan scholars and was adapted for the Ethiopian context. DKT consisting of 23 questions has been shown to adequately estimate general patient knowledge of diabetes. Only the first 14 questions were applied to patients who do not use insulin and the entire questionnaire were administered to patients who use insulin. The score for each participant was determined by dividing the number of correct answers by the total number of questions (14 for those receiving only oral hypoglycemic agents and 23 questions for patients taking insulin). To assess the level of knowledge of diabetes, we recorded the patients' level of knowledge into three groups on the basis of their DKT scores: as good, acceptable and poor knowledge if their overall score is $\geq 75 \%$, $60-74 \%$, and $\leq 59 \%$, respectively. The scores were used to determine overall knowledge level [20].

Body mass index (BMI) Body mass index (BMI) was categorized as normal weight if BMI was 18.5-24.9, 
Underweight if BMI was $<18.5$, overweight if BMI was $25-29.9 \mathrm{~kg} / \mathrm{m}^{2}$, and obese if BMI was $\geq 30 \mathrm{~kg} / \mathrm{m}^{2}$ based on the World Health Organization criteria [21].

\section{Results}

A total of 252 study participants were included in the study, of this $54.8 \%$ were male. The mean age of the participants was $41.7 \pm 17.6$ years. Out of the study participants $52.0 \%$ were in the age range of $30-60$ years. More than half of the study participants were unemployed $131(52.0 \%)$ and $129(51.2 \%)$ were from urban (Table 1).

Majority of the study participants 188 (74.6\%) had no family/social support and most of them 220 (87.3\%) had no family history of diabetes. More than half $61.1 \%$ of the participants treated for diabetes mellitus for less than 6 years. Only $10.3 \%$ of the participants had access for monitoring their blood glucose. About 159 (63.1\%) of the patients were taking only insulin. Majority 169 (67.1\%) of the participants had poor knowledge about diabetes. Of the participants 159 (63.1\%) patients had type $1 \mathrm{DM}$. More than half of the participants 150 (59.5\%) had poor glycemic control. One hundred fiftythree (60.7\%) participants had good self-care (Table 1).

Regarding self-care practice domains of diabetic patients majority of them 209 (82.9\%) had adequate foot care and more than half 175 (69.4\%) and 160 (63.5\%) had adequate dietary plan and exercise management respectively. However of the total diabetic patients only 38 (15.1\%) had adequate blood glucose testing practices (Table 2).

Variables like sex, educational status, occupation, residence, BMI, knowledge of diabetes and type of DM had shown statistically significant association $(\mathrm{p}<0.05)$ with self-care practices in bivariable analysis. In this study, variables with $\mathrm{p}$-value $<0.25$ were entered into multivariable analysis to identify independent predictors of poor self-care practices among diabetic patients (Table 3).

According to the result of multivariable logistic analysis poor self-care practices were more likely to occur among male patients $(\mathrm{AOR}=5.551,95 \%$ $\mathrm{CI}=2.055-14.997, \mathrm{p}=0.001)$, patients living in rural area $(\mathrm{AOR}=5.517,95 \% \mathrm{CI}=2.184-13.938$, $\mathrm{p}<0.001$ ), patients with duration of diabetes $<6$ years $(\mathrm{AOR}=41.023,95 \% \mathrm{CI}=7.373-228.257, \mathrm{p}<0.001)$, patients with no access for self-monitoring blood glucose $\quad(\mathrm{AOR}=9.448, \quad 95 \% \quad \mathrm{CI}=2.198-40.617$, $\mathrm{p}=0.003)$, patients with poor knowledge about diabetes $(\mathrm{AOR}=67.917,95 \% \mathrm{CI}=8.212-561.686, \mathrm{p}<0.001)$ and patients with comorbidities (AOR $=18.621,95 \%$ $\mathrm{CI}=4.415-78.540, \mathrm{p}<0.001)($ Table 3$)$.
Table 1 Socio-demographic and clinical characteristics of diabetic patients on follow up at Nekemte Referral Hospital, West Ethiopia, from February 20 to May 20, $2016(n=252)$

\begin{tabular}{|c|c|c|c|}
\hline Variables & Category & Frequency & Percentage \\
\hline \multirow[t]{2}{*}{ Sex } & Male & 138 & 54.8 \\
\hline & Female & 114 & 45.2 \\
\hline \multirow[t]{3}{*}{ Age } & $<30$ & 89 & 35.3 \\
\hline & $30-60$ & 131 & 52.0 \\
\hline & $>60$ & 32 & 12.7 \\
\hline \multirow[t]{4}{*}{ Educational status } & No formal education & 70 & 27.8 \\
\hline & Primary school & 97 & 38.5 \\
\hline & Secondary school & 48 & 19.0 \\
\hline & College/University & 37 & 14.7 \\
\hline \multirow[t]{3}{*}{ Occupation } & Employed & 48 & 19.0 \\
\hline & Unemployed & 131 & 52.0 \\
\hline & Farmer & 73 & 29.0 \\
\hline \multirow[t]{2}{*}{ Residence } & Urban & 129 & 51.2 \\
\hline & Rural & 123 & 48.8 \\
\hline \multirow[t]{4}{*}{ BMI } & $<18.5$ (Underweight) & 17 & 6.7 \\
\hline & $\begin{array}{l}\text { 18.5-24.9 (Normal } \\
\text { weight) }\end{array}$ & 142 & 56.3 \\
\hline & 25-29.9 (Overweight) & 50 & 19.8 \\
\hline & $\geq 30$ (Obese) & 43 & 17.1 \\
\hline \multirow[t]{2}{*}{ Family/social support } & Yes & 64 & 25.4 \\
\hline & No & 188 & 74.6 \\
\hline \multirow{2}{*}{$\begin{array}{l}\text { Family history of } \\
\text { diabetes }\end{array}$} & Yes & 32 & 12.7 \\
\hline & No & 220 & 87.3 \\
\hline \multirow[t]{3}{*}{ Duration of diabetes } & $<6$ & 154 & 61.1 \\
\hline & $6-10$ & 69 & 27.4 \\
\hline & $>10$ & 29 & 11.5 \\
\hline \multirow{2}{*}{$\begin{array}{l}\text { Number of medications } \\
\text { taken }\end{array}$} & 1 & 138 & 54.8 \\
\hline & $\geq 2$ & 114 & 45.2 \\
\hline \multirow{2}{*}{$\begin{array}{l}\text { Access for self-monitor- } \\
\text { ing blood glucose }\end{array}$} & Yes & 26 & 10.3 \\
\hline & No & 226 & 89.7 \\
\hline \multirow{2}{*}{$\begin{array}{l}\text { Hospitalization due } \\
\text { to diabetic related } \\
\text { problem }\end{array}$} & Yes & 53 & 21.0 \\
\hline & No & 199 & 79.0 \\
\hline \multirow[t]{3}{*}{ Knowledge of diabetes } & Good & 30 & 11.9 \\
\hline & Acceptable & 53 & 21.0 \\
\hline & Poor & 169 & 67.1 \\
\hline \multirow{5}{*}{$\begin{array}{l}\text { Anti-diabetic medica- } \\
\text { tion }\end{array}$} & Metformin & 57 & 22.6 \\
\hline & Insulin & 159 & 63.1 \\
\hline & Insulin and metformin & 10 & 4.0 \\
\hline & $\begin{array}{l}\text { Metformin and Glib- } \\
\text { enclamide }\end{array}$ & 21 & 8.3 \\
\hline & Glibenclamide & 5 & 2.0 \\
\hline \multirow{2}{*}{$\begin{array}{l}\text { Presence of comorbidi- } \\
\text { ties }\end{array}$} & Yes & 75 & 30.6 \\
\hline & No & 175 & 69.4 \\
\hline \multirow{2}{*}{$\begin{array}{l}\text { Type of diabetes mel- } \\
\text { litus }\end{array}$} & Type 1 & 159 & 63.1 \\
\hline & Type 2 & 93 & 36.9 \\
\hline \multirow[t]{2}{*}{ Glycemic control } & $\leq 130$ & 102 & 40.5 \\
\hline & $>130$ & 150 & 59.5 \\
\hline \multirow[t]{2}{*}{ Self-care } & Poor self-care & 99 & 39.3 \\
\hline & Good self-care & 153 & 60.7 \\
\hline
\end{tabular}


Table 2 Distribution of self-care practice domains diabetic patients on follow up at Nekemte Referral Hospital, West Ethiopia, from February 20 to May 20, $2016(n=252)$

\begin{tabular}{lcc}
\hline Self-care practice domains & Adequate & Unsatisfactory \\
\hline Diet & $175(69.4 \%)$ & $77(30.6 \%)$ \\
Exercise & $160(63.5 \%)$ & $92(36.5 \%)$ \\
Foot care & $209(82.9 \%)$ & $43(17.1 \%)$ \\
Blood glucose testing & $38(15.1 \%)$ & $214(84.9 \%)$ \\
\hline
\end{tabular}

\section{Discussion}

Self-monitoring of glycemic control is a cornerstone of diabetes care that can ensure patient participation in achieving and maintaining specific glycemic targets. Self-monitoring provides information about current glycemic status, allowing for assessment of therapy and guiding adjustments in diet, exercise and medication in order to achieve optimal glycemic control [22].

This study revealed that the self-care practices of diabetic patients accounts for $60.7 \%$. Self-care practices in this study is higher as compared to previous done studies in Harari [17], JUSH [23], India [24], which reported $50.9 \%, 39.2 \%, 46.4 \%$ of self-care practices; but lower than study done in Nigeria [25] which reported $79.5 \%$ of self-care practices. The differences in self-care practices could be due to easier access to health-related activities and higher proportions of literate population in the present study setting as compared to previously done studies in Ethiopia.

This study showed that male patients were 5.551 times more likely to had poor self-care practices as compared to female patients. This finding is consistent with that reported by other studies from Tikur Anbesa Specialized hospital [16], Nigeria [25] and Bangladesh [26]. This difference in gender shows difference in awareness over self-care practices and commitment for adhering to the self-care practices, thus education on self-care practices has to be provided for all diabetic patients.

The living places of the patients had shown significance association with poor self-care practices. Patients living in rural areas are 5.517 times more likely to develop poor self-care practices than those living in urban. Similar findings were reported from Ayder Comprehensive Specialized Hospital [27] and Bangladesh [26].

Patients with shorter duration of diabetes had shown significant association with poor self-care practices. Similar findings were reported from Ayder Comprehensive Specialized Hospital [27], Bangladesh [26] and United Arab Emirates [28]. The reasons for poor self-care in patients with shorter duration of diabetes could be due to less regular counseling and contact with health professionals that may help them to create their awareness for self-care practices.

Patients with no access for self-monitoring blood glucose were 9.448 times more likely to had poor self-care practices than those who had access for self-monitoring blood glucose. This finding is consistent with studies done at JUSH [23], California [29] and United Kingdom [30]. The reason for no access of self-monitoring blood glucose could be because of low socioeconomic status of the study participants and lack of their awareness on the use of glucometer.

Poor knowledge about diabetes was associated significantly with poor self-care practices. This finding is consistent with other studies done in Tikur Anbesa Specialized hospital [16] and Bangladesh [31]. This could be explained as patients with poor knowledge about diabetes are less compliant to their medication and self-care practice and this will result in poor glycemic control [10, 32, 33].

\section{Conclusion}

The present study concluded that self-care practices of study participants were poor. In particular blood glucose testing domain of self-care practice was very poor and relatively there were good foot care among the study participants. Thus we recommend that health care providers should begin by taking time to evaluate their patients' perceptions and make realistic and specific recommendations for self-care activities.

\section{Limitations}

Data about diabetes and self-care knowledge were selfreported; this method has the disadvantages of recall bias and eliciting only socially acceptable responses and hence, may, lead to overestimation of some of the results. 
Table 3 Logistic regression analysis of factors associated with self-care practices among diabetic patients on follow up at Nekemte Referral Hospital, West Ethiopia, from February 20 to May 20, $2016(n=252)$

\begin{tabular}{|c|c|c|c|c|c|}
\hline \multirow[t]{2}{*}{ Variables } & \multirow[t]{2}{*}{ Categories } & \multicolumn{2}{|c|}{$\begin{array}{l}\text { Self-care } \\
\text { practice }\end{array}$} & \multirow[t]{2}{*}{ COR $(95 \% \mathrm{Cl}) \mathrm{p}$ value } & \multirow[t]{2}{*}{ AOR $(95 \% \mathrm{Cl}) \mathrm{p}$ value } \\
\hline & & Good & Poor & & \\
\hline \multirow[t]{2}{*}{ Sex } & Male & 76 & 62 & $1.698(1.013-2.844) p=0.044$ & $5.551(2.055-14.997) p=0.001$ \\
\hline & Female & 77 & 37 & 1.00 & 1.00 \\
\hline \multirow[t]{3}{*}{ Age } & $<30$ & 48 & 41 & $0.854(0.380-1.917) p=0.702$ & - \\
\hline & $30-60$ & 89 & 42 & $0.472(0.215-1.034) p=0.060$ & - \\
\hline & $>60$ & 16 & 16 & 1.00 & - \\
\hline \multirow[t]{4}{*}{ Educational status } & No formal education & 36 & 34 & $1.744(0.767-3.966) p=0.185$ & $1.826(0.334-9.988) p=0.487$ \\
\hline & Primary school & 51 & 46 & $1.665(0.760-3.646) p=0.202$ & $2.026(0.471-8.718) p=0.343$ \\
\hline & Secondary school & 32 & 16 & $0.264(0.089-0.784) p=0.037$ & $0.127(0.018-1.098) p=0.063$ \\
\hline & College/University & 24 & 13 & 1.00 & 1.00 \\
\hline \multirow[t]{3}{*}{ Occupation } & Employed & 38 & 10 & 1.00 & - \\
\hline & Unemployed & 84 & 47 & $2.126(0.972-4.651) p=0.059$ & - \\
\hline & Farmer & 31 & 42 & $5.148(2.229-11.890) p<0.001$ & - \\
\hline \multirow[t]{2}{*}{ Residence } & Urban & 99 & 30 & 1.00 & 1.00 \\
\hline & Rural & 54 & 69 & $4.217(2.453-7.250) p<0.001$ & $5.517(2.184-13.938) p<0.001$ \\
\hline \multirow[t]{4}{*}{ BMI } & $<18.5$ & 15 & 2 & 1.00 & - \\
\hline & $18.5-24.9$ & 70 & 72 & $7.714(1.701-34.978) p=0.008$ & - \\
\hline & $25-29.9$ & 34 & 16 & $3.529(0.719-17.317) p=0.120$ & - \\
\hline & $\geq 30$ & 34 & 9 & $1.985(0.382-10.319) p=0.415$ & - \\
\hline \multirow[t]{2}{*}{ Family/social support } & Yes & 33 & 31 & 1.00 & - \\
\hline & No & 120 & 68 & $0.603(0.340-1.070) p=0.084$ & - \\
\hline \multirow[t]{2}{*}{ Family history of diabetes } & Yes & 15 & 17 & 1.00 & - \\
\hline & No & 138 & 82 & $0.524(0.249-1.106) p=0.090$ & - \\
\hline \multirow[t]{3}{*}{ Duration of diabetes } & $<6$ & 56 & 98 & $2.154(0.966-4.804) p=0.061$ & $41.023(7.373-228.26) p<0.001$ \\
\hline & $6-10$ & 27 & 42 & $1.125(0.627-2.018) p=0.693$ & $2.768(0.966-7.933) p=0.058$ \\
\hline & $>10$ & 16 & 13 & 1.00 & 1.00 \\
\hline \multirow[t]{2}{*}{ Number of medications taken } & 1 & 78 & 60 & 1.00 & - \\
\hline & $\geq 2$ & 75 & 39 & $0.676(0.405-1.129) p=0.135$ & - \\
\hline \multirow[t]{2}{*}{ Access for self-monitoring BG } & Yes & 19 & 7 & 1.00 & 1.00 \\
\hline & No & 134 & 92 & $1.864(0.753-4.613) p=0.178$ & $9.448(2.198-40.617) p=0.003$ \\
\hline \multirow{2}{*}{$\begin{array}{l}\text { Hospitalization due to diabetic } \\
\text { related problem }\end{array}$} & Yes & 30 & 23 & $1.241(0.672-2.292) p=0.491$ & - \\
\hline & No & 123 & 76 & 1.00 & - \\
\hline \multirow[t]{3}{*}{ Knowledge of diabetes } & Good & 28 & 2 & 1.00 & 1.00 \\
\hline & Acceptable & 41 & 12 & $4.098(0.851-19.738) p=0.079$ & $0.903(0.104-7.864) p=0.926$ \\
\hline & Poor & 84 & 85 & $14.167(3.271-61.36) p<0.001$ & $67.917(8.212-561.686) p<0.001$ \\
\hline \multirow[t]{5}{*}{ Anti-diabetic medication } & Metformin & 35 & 22 & 1.00 & - \\
\hline & Insulin & 85 & 74 & $1.385(0.747-2.569) p=0.301$ & - \\
\hline & Insulin and metformin & 8 & 2 & $0.398(0.077-2.048) p=0.270$ & - \\
\hline & Metformin and glibenclamide & 21 & 0 & 0.000 & - \\
\hline & Glibenclamide & 4 & 1 & $0.398(0.042-3.793) p=0.423$ & - \\
\hline \multirow[t]{2}{*}{ Presence of comorbidities } & Yes & 42 & 35 & $1.445(0.839-2.490) p=0.184$ & $18.621(4.415-78.540) p<0.001$ \\
\hline & No & 111 & 64 & 1.00 & 1.00 \\
\hline \multirow[t]{2}{*}{ Type of DM } & Type 1 & 85 & 74 & $2.368(1.360-4.122) p=0.002$ & - \\
\hline & Type 2 & 68 & 25 & 1.00 & - \\
\hline \multirow[t]{2}{*}{ Glycemic control } & $\leq 130$ & 64 & 38 & 1.00 & - \\
\hline & $>130$ & 89 & 61 & $1.154(0.688-1.936) p=0.586$ & - \\
\hline
\end{tabular}


The study period might be short but all the diabetic patients who came to hospital within study period and satisfied the inclusion criteria.

\author{
Abbreviations \\ AOR: adjusted odds ratio; BMI: body mass index; COR: crude odds ratio; DKT: \\ Diabetes Knowledge Test; DM: diabetes mellitus; FBG: fasting blood glucose; \\ HbA1c: glycosylated hemoglobin; MCQ: multiple choice questions; NRH: \\ Nekemte Referral Hospital; SDSCA: Summary Diabetes Self-Care Activi- \\ ties; SPSS: Statistical Program for the Social Sciences; WHO: World Health \\ Organization.
}

\section{Authors' contributions}

MGD:-contributed to the study design, set the objective, participated in data collection and analysis, and participated in editing the manuscript. BME:-contributed to the study design, set the objective, participated in data analysis, and participated in editing the manuscript. GBW:-contributed to the study design, set the objective, participated in data analysis, and participated in editing the manuscript. GFM:-contributed to the study design, set the objective, participated in data analysis, and participated in editing the manuscript. BGL:-contributed to the study design, set the objective, participated in data analysis, and participated in editing the manuscript. All authors read and approved the final manuscript.

\section{Author details}

${ }^{1}$ Clinical Pharmacy Unit, Department of Pharmacy, College of Health Sciences, Wollega University, Nekemte, Oromia, Ethiopia. ${ }^{2}$ Pharmaceutics Unit, Department of Pharmacy, College of Health Sciences, Wollega University, Nekemte, Oromia, Ethiopia.

\section{Acknowledgements}

We are grateful to the department of pharmacy, Wollega University for their unreserved cooperation in making this study to be a fruitful work. We are also thankful for the outpatient department nurses of Nekemte Referral Hospital for their cooperation in collecting the data and the patients who willingly participate in this study.

\section{Competing interests}

The authors declare that they have no competing interests.

\section{Availability of data and materials}

Data and materials are available with the authors and will be available up on request.

\section{Consent for publication}

Not applicable.

\section{Ethics approval and consent to participate}

Ethical clearance was obtained from the Ethical Review Committee of Wollega University, College of Medical and Health Sciences. This committee wrote a formal letter of permission to Nekemte Referral Hospital to seek its cooperation and access to the patients and data. Permission was obtained from the medical director's office of the hospital. Patient's written informed consent and written parental consent for participants under 16 was obtained after explaining about the purpose and procedures of the study. The confidentiality of study participants was secured. In addition all the responses were kept confidential.

\section{Funding}

Not applicable.

\section{Publisher's Note}

Springer Nature remains neutral with regard to jurisdictional claims in published maps and institutional affiliations.

Received: 8 March 2019 Accepted: 3 April 2019

Published online: 08 April 2019

\section{References}

1. Sicree R, Shaw J, Zimmet P. The global burden: diabetes and impaired glucose tolerance. 4th ed. Brussels: IDF Diabetes Atlas; 2009.

2. American Diabetic Association. Standards of Medical Care in Diabetes. Diabetes Care. 2009;32:S13-61.

3. American Diabetic Association. Standards of Medical Care in Diabetes. Diabetes Care. 2014;37:S14-80.

4. International Diabetes Federation. IDF Diabetes Atlas, 8th ed. Brussels: Diabetes Atlas; 2017.

5. IDF Diabetes Atlas Group. Update of mortality attributable to diabetes for the IDF Diabetes Atlas: estimates for the year 2011. Diabetes Res Clin Pract. 2013;100:277-9.

6. Sanal TS, Nair NS, Adhikari P. Factors associated with poor control of type 2 diabetes mellitus: a systematic review and Meta-analysis. J Diabetol. 2011;3:1.

7. Al-Hayek AA, Robert AA, Alzaid AA, Nusair HM, Zbaidi NS, Al-Eithan MH, et al. Association between diabetes self-care, medication adherence, anxiety, depression, and glycemic control in type 2 diabetes. Saudi Med J. 2012;33(6):681-3.

8. Ulvi OS, Chaudhary RY, Ali T, Alvi RA, Khan MFA, Khan M, et al. Investigating the awareness level about Diabetes Mellitus and associated factors in Tarlai (Rural Islamabad). J Pak Med Assoc. 2009;59(11):798-801.

9. Mohammadi S, Karim NA, Talib RA, Amani R. Knowledge, attitude and practices on diabetes among type 2 diabetic patients in iran: a crosssectional study. Sci J Public Health. 2015;3(4):520-4.

10. Khattab M, Khader YS, Al-Khawaldeh A, Ajlouni K. Factors associated with poor glycemic control among patients with Type 2 diabetes. J Diabetes Complications. 2010;24:84-9.

11. Gudina EK, Amade ST, Tesfamichael FA, Ram R. Assessment of quality of care given to diabetic patients at Jimma University Specialized Hospital diabetes follow-up clinic, Jimma, Ethiopia. BMC Endocr Disord. 2011;11:19.

12. Worku D, Hamza L, Woldemichael K. Patterns of diabetic complications at Jimma University Specialized Hospital, Southwest Ethiopia. Ethiop J Health Sci. 2010;20(1):33-9.

13. Feleke SA, Alemayehu CM, Adane HT. Assessment of the level and associated factors with knowledge and practice of Diabetes Mellitus among Diabetic Patients attending at FelegeHiwot Hospital, Northwest Ethiopia. Clin Med Res. 2013;2(6):110-20.

14. Hailu E, Mariam WH, Belachew T, Birhanu Z. Self-care practice and glycaemic control amongst adults with diabetes at the Jimma University Specialized Hospital in south-west Ethiopia: a cross-sectional study. Afr J Prm Health Care Fam Med. 2012;4(1):311-6.

15. Teklay G, Hussien J, Tesfaye D. Non-adherence and associated factors among type 2 diabetic patients at Jimma University Specialized Hospital, Southwest Ethiopia. J Med Sci. 2013;13(7):578-84.

16. Berhe KK, Kahsay AB, Gebru HB. Adherence to diabetes Self-management practices among type II diabetic patients in Ethiopia; a cross sectional study. Greener J Med Sci. 2013;3(6):211-21.

17. Ayele K, Tesfa B, Abebe L, Tilahun T, Girma E. Self-care behavior among patients with diabetes in Harari, Eastern Ethiopia: The Health Belief Model Perspective. PLOS ONE. 2012;7(4):e35515.

18. Glasgow RE, Strycker LA. Preventive care practices for diabetes management in two primary care samples. Am J Prev Med. 2000;19(1):9-14.

19. Toobert DJ, Hampson SE, Glasgow RE. The summary of diabetes self-care activities measure: results from 7 studies and a revised scale. Diabetes Care. 2000;23(7):943-50.

20. Fitzgerald JT, Funnell MM, Hess GE, Barr PA, Anderson RM, Hiss RG, et al. The reliability and validity of a brief Diabetes Knowledge Test. Diabetes Care. 1998;21(5):706-10.

21. World Health Organization. Physical status: The use and interpretation of anthropometry: report of a WHO Expert committee. Technical report series 854. Geneva: World Health Organization; 1995.

22. Shrivastava SR, Shrivastava PS, Ramasamy J. Role of self-care in management of diabetes mellitus. J Diabetes Metab Disord. 2013;12:14.

23. Kassahun T, Gesesew H, Mwanri L, Eshetie T. Diabetes related knowledge, self-care behaviours and adherence to medications among diabetic patients in Southwest Ethiopia: a cross-sectional survey. BMC Endocr Disord. 2016;16:28.

24. Selvaraj K, Ramaswamy G, Radhakrishnan S, Thekkur P, Chinnakali P, Roy G. Self-care practices among diabetes patients registered in a 
chronic disease clinic in Puducherry, South India. J Soc Health Diabetes. 2016:4:25-9.

25. Jackson IL, Adibe MO, Okonta MJ, Ukwe CV. Knowledge of self-care among type 2 diabetes patients in two states of Nigeria. Pharm Pract. 2014;12(3):404

26. Rahaman KS, Majdzadeh R, Naieni KH, Raza O. Knowledge, Attitude and Practices (KAP) regarding chronic complications of diabetes among patients with type 2 diabetes in Dhaka. Int J Endocrinol Metab. 2017;15(3):e12555.

27. Niguse H, Belay G, Fisseha G, Desale T, Gebremedhn G. Self-care related knowledge, attitude, practice and associated factors among patients with diabetes in Ayder Comprehensive Specialized Hospital, North Ethiopia. BMC Res Notes. 2019;12:34.

28. Al-Maskari F, El-Sadig M, Al-Kaabi JM, Afandi B, Nagelkerke N, et al. Knowledge, attitude and practices of diabetic patients in the United Arab Emirates. PLoS ONE. 2013;8(1):e52857. https://doi.org/10.1371/journ al.pone.0052857.
29. Ahmed AT, Karter AJ, Liu J. Alcohol consumption is inversely associated with adherence to diabetes self-care behaviours. Diabet Med. 2006;23(7):795-802.

30. Knott Katy E. Alcohol consumption and adherence to self-care behaviours in type 2 diabetes; the inclusion of Brief Interventions for alcohol in diabetes care. UK: University of Leicester; 2013.

31. Saleh F, Mumu SJ, Ara F, Begum HA, Ali L. Knowledge and self-care practices regarding diabetes among newly diagnosed type 2 diabetics in Bangladesh: a cross-sectional study. BMC Public Health. 2012:12:1112.

32. Ashur ST, Shah SA, Bosseri S, Fah TS, Shamsuddin K. Glycaemic control status among type 2 diabetic patients and the role of their diabetes coping behaviours: a clinic-based study in Tripoli, Libya. Libyan J Med. 2016:11:31086.

33. Kubais MNA, Hassan NAGM, Shamsain MH. Association between adherence to diabetes medication and glycemic control. Int J Res Dev Pharm L Sci. 2016;5(1):1915-20.
Ready to submit your research? Choose BMC and benefit from:

- fast, convenient online submission

- thorough peer review by experienced researchers in your field

- rapid publication on acceptance

- support for research data, including large and complex data types

- gold Open Access which fosters wider collaboration and increased citations

- maximum visibility for your research: over 100M website views per year

At BMC, research is always in progress.

Learn more biomedcentral.com/submissions 